\title{
Does vegetation impact on the population dynamics and male function in Anemone sylvestris L. (Ranunculaceae)? A case study in three natural populations of xerothermic grasslands
}

\author{
Bożena Denisow', Małgorzata Wrzesień2* \\ 'Department of Botany, Laboratory of Horticultural Plants Biology, University of Life Sciences in Lublin, Akademicka 15, 20-950 Lublin, Poland \\ ${ }^{2}$ Department of Geobotany, Institute of Biology and Biochemistry, Maria Curie-Skłodowska University, Akademicka 19, 20-033 Lublin, Poland
}

\begin{abstract}
In Poland, like in other parts of Central Europe, dry grasslands significantly contribute to the biodiversity of both fauna and flora. Anthropogenic pressure impair many species of xerothermic habitats, and several populations face an increased risk of extinction. The goal of the study was to define factors that may affect the size of wild populations of Anemone sylvestris L., a protected species in Poland, with both a short- and long-term perspective, and to examine the influence of vegetation changes on the density, the abundance of flowering and male function (pollen production, pollen viability), as well as seed set. In situ observations were performed in 2005-2006 and 2011-2012 in three populations located on the Lublin Upland, SE Poland. The reduction in population density and A. sylvestris blooming was exacerbated by the expansion of the shrubs, but not by Brachypodium pinnatum. Male characteristics of A. sylvestris, i.e. pollen amount per multi-staminate flowers or pollen viability appeared to decrease under pressure of shrub competition. Populations with limitation of male function had impaired degree of seed set. Various consequences for the functioning of populations within a metapopulation system can be expected due to substantial qualitative and quantitative disorders in pollen traits. It is crucial that successful recovery programs for A. sylvestris primary should aim to conserve and manage the habitat.
\end{abstract}

Keywords: rare species; shrubs expansion; pollen mass; pollen viability; seed set

\section{Introduction}

Dry grasslands are among the most important habitats of Central and Eastern Europe and are regarded as steppelike "warm-stage refuge" [1-3]. These habitats significantly contribute to the biodiversity of both flora and fauna [4-6]. The xerothermic vegetation has become strongly endangered, dramatic losses are due to habitat destruction, fragmentation, secondary succession, or even competition from invasive species [7-10].

Many species of dry grasslands occur in small populations and face an increased risk of extinction [11,12]; hence, one of the main priorities of the European Plant Conservation Strategy under the Bern Convention and nature conservation policy is the monitoring of populations of rare and threatened plant species to counteract the reduction of their abundance.

In Poland, like in other parts of Central Europe, grasslands are under secondary succession pressure and are overgrown by shrubs and trees. This inhibits the reproduction

* Corresponding author. Email: mseptember@tlen.pl

Handling Editor: Aleksandra Samecka-Cymerman of many herb species and may lead to their local extinction [9]. The maintenance of the species richness and composition of semi-natural grasslands is possible by the traditional methods of management, i.e. controlled grazing or mowing $[4,8]$. However, a number of studies have pointed out that the regeneration of the xerothermic vegetation, including rare species may be very weak; the principal reason is a limited availability of seeds and/or problems with vegetative spread of such species [13,14].

The propagation by vegetative reproduction dominates in established populations of clonal plants $[11,15,16]$. Nevertheless, sexual reproduction is critical because ensures a unique genetic population structure, secure adaptation of individuals to changeable environmental conditions [17], and enable the establishment of new populations $[15,18]$, although it rarely occurs [19].

Species from the Ranunculaceae, including the genus Anemone develop flowers that are attractive for insects [19,20-23] and produce copious amounts of pollen [24]. Pollen plays a key role in sexual reproduction and has an impact on individual fitness, population genetics, population dynamics, and the metapopulation system [25,26]. Different interdependent factors may influence pollen dispersal between individuals and among spatially separated populations, 
i.e. density of individuals and the activity of insect visitors are considered as most important [27-33]. Numerous studies have shown that plant reproductive problems are often a male-related and attributable to pollen production or quality, i.e. decreasing pollen viability or low pollen-tube survival [25,34-38]. Disorders in the complement of male and/or female function are particularly severe for small isolated populations and may deepen their weakening by the spread of inbreeding depression [39-42]. However, still little is known about variation in pollen productivity among or within populations.

The paper is one of a series of monitoring studies of rare and endangered entomophilous species across xerothermic grasslands [43-46]. The main goal in this study was to define factors that may affect the size of three wild populations of Anemone sylvestris with both a short- and long-term perspective. Firstly, we attempted to examine the influence of vegetation changes on the density of $A$. sylvestris. We also try to estimate the extent of intra- and interpopulational variations in $(\boldsymbol{i})$ the abundance of flowering, (ii) pollen production, (iii) pollen viability, and finally (iv) we quantified the reproductive success.

\section{Material and methods}

\section{Study sites}

In situ observations were performed in 2005-2006 and 2011-2012 in three populations of Anemone sylvestris L. occurring in xerothermic grasslands, located on the Lublin Upland, SE Poland. The study patches covered an area of approx. $100-160 \mathrm{~m}^{2}$.

Experimental patch No. I - SG population. The xerothermic grasslands at Stawska Góra $\left(51^{\circ} 13^{\prime} \mathrm{N}, 23^{\circ} 25^{\prime} \mathrm{E}\right)$ is a nature reserve (Tab. 1). Annual precipitation averages 540 $\mathrm{mm}$. The area is composed of a mosaic of vegetation. A loose grassland patch of Brachypodio-Teucrietum Fijałkowski 1961 from the Festuco-Brometea Br.-Bl. Et R. Tx. 1943 dominated in the years 2005-2006 and covered approx. 90\% of the area. The experimental patch was overgrown and the xerothermic bushes of the Rhamno-Prunetea Rivas Goday et Garb. 1961 covered approx. $45 \%$ of the area in 2011 . To counteract the patch overgrowing, mowing intervention was undertaken by local authorities in the early spring of 2011.

Experimental patch No. II - KA population. The xerothermic grassland at Kąty $\left(50^{\circ} 42^{\prime} \mathrm{N}, 23^{\circ} 04^{\prime} \mathrm{E}\right)$ is situated in the area with annual precipitation $590 \mathrm{~mm}$. The slope is surrounded by the edges of pine-oak forests. The Inuletum ensifoliae Kozł. 1925 and Brachypodium pinnatum (L.) P. Beauv. covered the area. Typical xerothermic species i.e. Brachypodium pinnatum, Peucedanum cervaria (L.) Lapeyr., Salvia pratensis L., Campanula sibirica L., and Thalictrum minus L., were accompanied by tall herbs (Origanum vulgare L. and Galium verum L.) belonging to the Trifolio-Geranietea sanguinei Th. Müller 1962. Rare and endangered taxa were also present, e.g. Linum flavum L., Cerasus fruticosa Pall., Peucedanum alsaticum L., Orchis purpurea Huds., and Orchis militaris $\mathrm{L}$.

Experimental patch No. III - PE population. The xerothermic grassland in Podzamcze $\left(51^{\circ} 01^{\prime} \mathrm{N}, 23^{\circ} 31^{\prime} \mathrm{E}\right)$ was located in the area with annual precipitation ca. $550 \mathrm{~mm}$. The Inuletum ensifoliae was dominanting. Accompanying herbs were Achillea pannonica Scheele, Asperula tinctoria L., Campanula sibirica, Cirsium pannonicum (L. F.) Link., and Anthyllis vulneraria L. The xerothermic shrubs from the Rhamno-Prunetea class were formed by Prunus spinosa L., Juniperus communis L., Cerasus fruticosa, Berberis vulgaris L., and Cornus sanguinea L. It covered approx. $10 \%$ in 2005-2006 and increased up to 30\% in 2011-2012.

\section{Study species}

Anemone sylvestris L. (Ranunculaceae), the snowdrop windflower, is a heliophyte and long-lived, rhizomatous plant that has a possibility of asexual and sexual reproduction [47]. Growth, flowering, fruit ripening and dispersal is completed between April and June, and all aboveground organs then wither. The flower is cup-shaped, actinomorphic, perfect, and protogynous. Flower parts are arranged spirally on a convex receptacle: white or pink sepals, numerous anthers, and numerous apocarpic carpels, each of which contains a single ovule $[47,48]$. Flowering occurs when the day temperature fluctuates between $8-21^{\circ} \mathrm{C}$. Anemone sylvestris is of the Eurosiberian range, with most stations occurring in Central and Southern Europe [49]. In Poland, the species is protected [50].

\section{Vegetation study}

The full spectrum of vascular plant species present on the patches was established every year by listing species in mid May at the time when spring flowers were still present and recognizable, and seedlings of summer species were identifiable. The abundance of all species was estimated on the basis of Braun-Blanquet scale [51]. The syntaxonomic units were described according to Matuszkiewicz [52], and the nomenclature of vascular plants was based on Mirek et al. [53].

Tab. 1 Location, some abiotic conditions and vegetation characteristics of xerothermic grasslands with Anemone sylvestris populations studied in Stawska Góra (SG), Kąty (KA) and Podzamcze (PE), SE Poland.

\begin{tabular}{lll} 
Study station & Habitat (a.s.l., slope, inclination, soil) & Vegetation \\
\hline SG & $\begin{array}{l}224.8 \mathrm{~m}, \mathrm{SW}, 15^{\circ} \text {, shallow rendzina on eroded } \\
\text { chalck, } \mathrm{pH}=7.4\end{array}$ & $\begin{array}{l}\text { Brachypodio-Teucrietum, Rhamno-Prunetea } \\
\text { KA }\end{array}$ \\
$\begin{array}{l}255 \mathrm{~m}, \mathrm{SE}, 15^{\circ}, \text { shallow rendzina on chalck, } \\
\mathrm{pH}=7.5\end{array}$ & $\begin{array}{l}\text { Inuletum ensifoliae, com. with Brachypodium } \\
\text { pinnatum }\end{array}$ \\
$\mathrm{PE}$ & $260 \mathrm{~m}, \mathrm{SE}, 20^{\circ}$, rendzina, $\mathrm{pH}=7.3$ & \begin{tabular}{l} 
Inuletum ensifoliae, Rhamno-Prunetea \\
\hline
\end{tabular}
\end{tabular}




\section{Population density and flowering study}

During the peak of flowering seasons, the population density and the number of flowers was estimated. We counted the individual plants and flowering shoots in a random sample of 30 circular areas of $0.1 \mathrm{~m}^{2}(36.7 \mathrm{~cm}$ in diameter $)[45,46]$.

\section{Androecium traits and pollen productivity}

The number of stamens per flower was determined for flowers $(n=24-30)$ randomly chosen in the peak of population flowering. The anther size was determined on the basis of dry weight of anthers. The amount of pollen obtained from the flowers strongly correlates positively with the size of anthers and the number of anthers per flower therefore we estimated mass of pollen (in $\mathrm{mg}$ ) rather than number of pollen grains $[20,54]$. To assay this mature but unopened anthers were randomly chosen from different flower buds $(n=18-29)$. The anthers were separated from filaments and collected in tarred glass containers (four replicates with 100 anthers for each population and year of study). The glass containers were placed in a dryer (ELCON CL 65) at ca. $33^{\circ} \mathrm{C}$. The anthers were separated and the pollen was rinsed from the anthers once with pure ether (1-2 ml) and then 4-6 times with $70 \%$ ethanol $(2-8 \mathrm{ml})$. The accuracy of the pollen rinsing was checked using a dissecting microscope under $\times 5$ power. The pollen was dried and weighted using a WPS-36 analytical balance (RADWAG, Poland). Then the pollen mass was calculated per flower.

\section{Pollen viability}

The proportion of pollen grains with viable protoplast was assessed in a standard $2 \%$ acetocarmine solution and observed in microscopic slides (Nikon Eclipse E 200). Flowers at anthesis were randomly harvested and fresh pollen was collected on microscopic glasses in the laboratory. In this test, pollen grains with cytoplasm stained red were considered as viable and with cytoplasm that remained transparent as nonviable. Pollen grains $(n=3 \times 100)$ were examined in $7-10$ localities across the slides. Pollen viability is expressed as the percentage of stained grains in the total analyzed.

\section{Fruit and seed set}

As the pistils have only one ovule, the degree of seed set was assessed as the percentage of well-developed achenes of the total number of pistils per flower [40]. The observations were made in randomly selected flowers $(n=32-36$ per population). The aborted vs. good achenes were easily recognized by the color: seedless achenes were turn brown, while fruits with a properly developed seed were yellowish green.

\section{Climatic data}

In particular years of the study, climatic data were taken from the meteorological stations located close to the experimental populations, i.e. in Włodawa (for SG population), in Zamość (for KA population) and in Radawiec (for PE population; http://en.tutiempo.net/climate/) [55]. The weather data used for the statistical RDA analysis corresponded to the periods of both generative ("g") - April-May, and vegetative ("v") - June-July phases of Anemone sylvestris development. For each period, the original data included the following weather parameters: mean air temperature
$-\mathrm{T}\left({ }^{\circ} \mathrm{C}\right)$, mean relative air humidity - $\mathrm{RH}(\%)$, and sums of rainfalls $-\mathrm{R}(\mathrm{mm})$.

\section{Data analysis}

We used a variety of approaches to define the factors that may impact the variability of Anemone sylvestris characteristics. The vegetation within the particular experimental sites was described by Shanon index and the similarity was established by the Jaccard index as: $S=a / a+b+c$, where: $a$ is the number of species common to both relevés; $b$ is the number of species common to the releve from 2005; $c$ is the number of species common to the relevé from 2011 or 2012. This index ranges from 0 (indicating no similarity in the community composition between the years) to 1 (indicating complete overlap). The multivariate statistical package (MVSP ver. 3.1) [56] was used for these analyses.

Multivariate ordination method in CANOCO ver. 5 [57] was used to analyze the relationship between variation in species composition within the entire data set of vegetation and environmental variables (Tab. 2). According to the length of the gradient (2.1) from a preliminary principal components analysis (PCA), a linear model (RDA) for environmental variables and flora of investigated sites was used. The statistical significance of the environmental variables and RDA axes was tested by the Monte Carlo permutation test (499 permutations) and interactive-forward data selection. Strong correlation was revealed between the mass of pollen per flower and the number of anthers and between the mass of pollen per flower and the size of anthers, therefore only the mass of pollen per flower was computed [57]. Finally all vegetation data sampled on study sites during the years of study with 5 environmental variables sets were included in the analyses. The eigenvalues and percentages of variance explained by the canonical axes were calculated.

Standard ANOVA procedures were applied to assess the difference in the mean values of the analyzed criteria of Anemone sylvestris among the three populations and within populations among the years of the study. To detect differences among the means, post hoc comparison was made by the Tukey's HSD test. The normality of the data was evaluated prior to the analysis. Pearson's correlation coefficient $(r)$ was applied to measure the strength of the relationship between the mass of pollen obtained in flowers and mass of pollen in anthers; anthers size = dry mass of anthers, and number of anthers. The level of statistical significance to measure the differences between the means for all the analyses was at $\alpha=$ 0.05 . Statistica software package version 10, developed by StatSoft Kraków was applied for these analyses [58].

\section{Results}

\section{Relationship between vegetation changes and environmental variables}

The first two axis displayed in the ordination diagram explained $60.9 \%$ of the variation, and the total variation explained by all the axes was $80.7 \%$ (Fig. 1, Tab. 2).

The gradient of the axis 1 was consistent with the increase in the degree of shrub cover in the xerothermic grasses; the axis $P$ value $=0.55$. The axis 2 revealed a loading to 
Tab. 2 Environmental variables measured concurrently with vegetation surveys and their contribution to the RDA model.

\begin{tabular}{|c|c|c|c|}
\hline Variable & $\begin{array}{l}\text { Variable } \\
\text { code }\end{array}$ & $\begin{array}{l}\text { Simple } \\
\text { effects }\end{array}$ & $\begin{array}{c}\text { Conditional } \\
\text { effects }\end{array}$ \\
\hline Pollen viability; in \% & PV & $28.6^{* *}$ & $28.6^{* *}$ \\
\hline $\begin{array}{l}\text { Seed set; } \% \text { in relation to } \\
\text { ovules per flower }\end{array}$ & SE & $27.7^{\star *}$ & $25.2^{* *}$ \\
\hline $\begin{array}{l}\text { Pollen mass; mean in mg per } \\
\text { flower }\end{array}$ & $\mathrm{PM}$ & $23.5^{\star *}$ & $5.2^{\mathrm{ns}}$ \\
\hline $\begin{array}{l}\text { Percentage of coverage; area } \\
\text { open from shrubs }\end{array}$ & $\mathrm{Shr}_{-}$ & $22.6^{*}$ & $2.4^{\mathrm{ns}}$ \\
\hline $\begin{array}{l}\text { Flowering abundance; mean } \\
\text { number of flowers per } 1 \mathrm{~m}^{2}\end{array}$ & FL & $20.1^{*}$ & $12.9^{* *}$ \\
\hline $\begin{array}{l}\text { Humidity in the generative } \\
\text { phase }\end{array}$ & $\mathrm{RHv}$ & $18.7^{\mathrm{ns}}$ & $5.7^{\mathrm{ns}}$ \\
\hline $\begin{array}{l}\text { Humidity in the vegetative } \\
\text { phase }\end{array}$ & $\mathrm{RHg}$ & $14.3^{\text {ns }}$ & $2.3^{\text {ns }}$ \\
\hline $\begin{array}{l}\text { Rainfalls in the vegetative } \\
\text { phase }\end{array}$ & $\mathrm{Rv}$ & $9.8^{\mathrm{ns}}$ & $5.4^{\mathrm{ns}}$ \\
\hline $\begin{array}{l}\text { Mean temperature in the } \\
\text { generative phase }\end{array}$ & $\mathrm{Tg}$ & $8.2^{\mathrm{ns}}$ & $4.6^{\mathrm{ns}}$ \\
\hline $\begin{array}{l}\text { Mean temperature in the } \\
\text { vegetative phase }\end{array}$ & $\mathrm{Tv}$ & $5.8^{\mathrm{ns}}$ & $4.0^{\mathrm{ns}}$ \\
\hline $\begin{array}{l}\text { Rainfalls in the generative } \\
\text { phase }\end{array}$ & $\operatorname{Rg}$ & $5.2^{\mathrm{ns}}$ & $3.2^{\mathrm{ns}}$ \\
\hline
\end{tabular}

${ }^{\star} P<0.05 ;{ }^{\star *} P<0.001 ;$ ns - non significant.

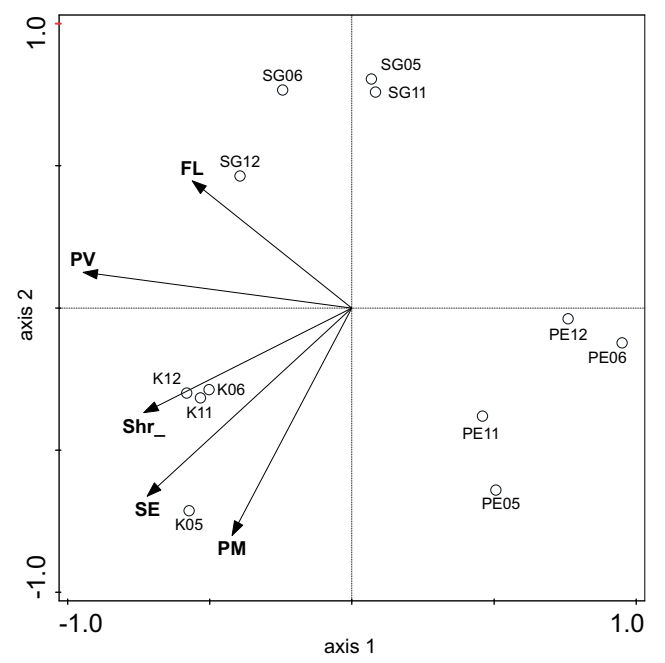

Fig. 1 Ordination biplot based on redundancy analysis (RDA) of the plant species matrix comprising all species sampled in three xerothermic grasslands with Anemone sylvestris during the years of study. Each point referes to the station and year of study, and vector labels refer to environmental variables (see Tab. 2 for definition). Stations: SG05-SG12, KA05-KA12, PE05-PE12; environmental variables: Shr_ - open space, FL - flowering abundance, PM - pollen mass, PV - pollen viability, SE - seed set; climatic conditions: $\mathrm{T}$ - mean air temperature, $\mathrm{RH}$ - mean relative air humidity, $\mathrm{R}$ - total rainfall, $\mathrm{g}$ - during the generative phase, $\mathrm{v}$ - during the vegetative phase. The diagram explains $80.77 \%$ of total variance (the first two eigenvalues: 0.34 and 0.28 ): axis $1-P=0.55$; axis $2-P=0.44$. the density of individuals of Anemone sylvestris; the axis $P$ value $=0.44$ (Fig. 1). The changes in A. sylvestris density and variability in the coverage of $(\boldsymbol{i})$ shrubs, (ii) Brachypodium pinnatum and (iii) herbs within the study plots are also shown on Fig. 2.

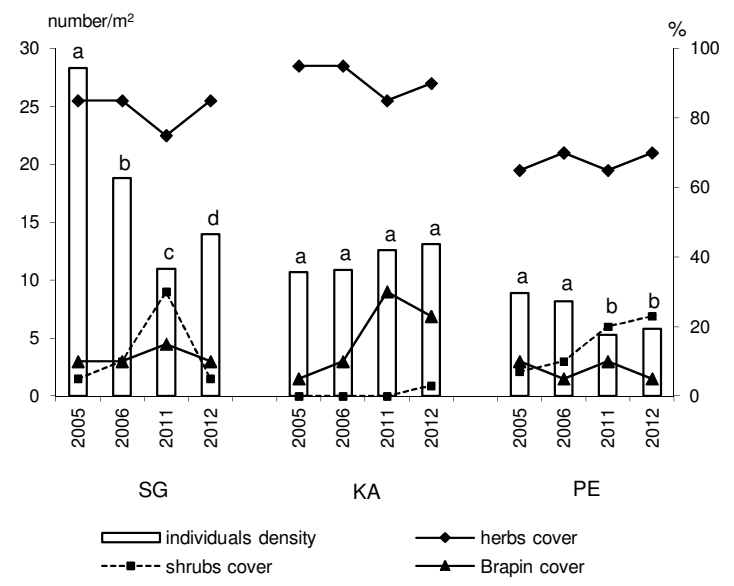

Fig. 2 The differences in density of Anemone sylvestris individuals and the cover of shrubs, Brachypodium pinnatum and herbs between growing seasons across three study xerothermic grasslands in SG, KA and PE. Means with the same small letter do not differ significantly between years within populations, according to Tukey's test.

The dry grasslands studied differed in the distribution and composition of species. The points of KA station characterised by open canopy stands with lack of shrubs are positioned on the negative side of the axis 1 , the vegetation here was most stable ( $S=0.72$ between 2005/2012), although the area was subjected to the invasion of $B$. pinnatum (coverage range 5-30\%; Tab. 3). The PE station with different degree of shrubs cover is situated on the positive side of the axis 1 . The increase in shrubs cover was ca. $18 \%$ here ( $S=0.51$ between $2005 / 2012$ ). In contrast, the area of open xerothermic grasslands at SG station decreased considerably due to the expansion of secondary succession of bush communities. The greatest change of vegetation at SG station between 2005 and 2011 occurred $(S=0.33)$, however after the mowing intervention (early spring in 2011), increased similarity with 2005 vegetation was evident $(S=0.49$ between 2005/2012). Therefore SG points are positioned both on the negative and positive sides of the axis 1 .

Tab. 3 The Jaccard index of similarity $(S)$ for vegetation between growing seasons within three xerothermic grasslands with Anemone sylvestris. For full description of the index see method.

\begin{tabular}{llcl} 
& \multicolumn{3}{c}{ Station } \\
\cline { 2 - 4 } Years & SG & KA & PE \\
\hline $2005 / 2006$ & 0.72 & 0.88 & 0.68 \\
$2005 / 2011$ & 0.33 & 0.70 & 0.78 \\
$2005 / 2012$ & 0.49 & 0.72 & 0.51 \\
$2011 / 2012$ & 0.48 & 0.66 & 0.45 \\
\hline
\end{tabular}


According to the RDA results five statistically significant components of the simple term effects were found for: pollen viability ( $\mathrm{PV}-28.6 \%)$, seed set ( $\mathrm{SE}-27.7 \%)$, pollen mass (PM - 23.5\%), open space (Shr_ - 22.6\%), and flowering abundance (FL - 20.13\%). Every weather parameters showed insignificant both simple term effects and conditional effects. Only three environmental variables had significant conditional effects: pollen viability (PV $-28.6 \%)$, seed set (SE $-25.5 \%$ ), and flowering abundance (FL $-12.9 \%$; Tab. 2). The relation of seed set and pollen characteristics to the shrubs invasion (light conditions, resource availability) could be indicated from their correlation with the Shr_arrow (Fig. 1).

\section{Population density and flowering of Anemone sylvestris}

The average density of individuals varied from 7.1 to 18.0 per $1 \mathrm{~m}^{2}$ among the populations (Fig. 1, Fig. 2). Two out of the three populations experienced to substantial transformation of the individuals density and the abundance of flowering among the years of the study. A particularly dramatic change, i.e. an almost $61 \%$ decrease in the density of plants, was noted between 2005 and 2011 in SG population. Then the increase in population density (ca. 25\%) and in the number of developed flowers (ca. 45\%) was observed between 2011 and 2012. No substantial change was observed in short-term in the PE population. The similar density of individuals and the number of flowers was noted both between 2005 and 2006 and between 2011 and 2012. In contrast, an almost $35 \%$ decrease in the density was found in long-term (between 2005 and 2012). The KA population exhibited considerable year-to-year stability both in the density and in the abundance of flowering; changes in density were below $5 \%$. Similar trends were observed for the number of flowers developed per unit area (Fig. 3a; ANOVA year $\times$ population $\mathrm{F}_{3,106}=19.69, P<0.001$; significant effects for SG and PE populations).

\section{Variations in pollen traits}

In general, the mass of pollen produced in anthers, the mass of pollen per flower, and pollen viability varied significantly from population to population (Fig. 3b,c); and from year-to-year within populations. The mass of pollen produced in anthers was positively related to anther size $(r=0.872, P<0.05)$, however negatively correlated to the number of anthers per flower $(r=-0.223, P<0.05)$. Generally, the amount of pollen obtained from the flowers strongly correlated positively with the mass of pollen produced in anthers $(r=0.951, P<0.05)$, and with the number of anthers per flower $(r=0.729, P<0.05)$. Across all the populations, the flowers of KA population produced almost 2-4 fold more pollen then flowers from PE and SG population. The greatest year-to-year fluctuations in pollen mass were noted in flowers from SG and PE populations. For example, in SG population, the mass of produced pollen was similar in 2005 and 2006 and increased in 2011 and 2012, compared to 2005 by $91 \%$ and $178 \%$, respectively. In contrast, in PE population a considerable decrease (75\%) in the mass of pollen produced per flower was found between 2005 and 2012.

The highest percentage of viable pollen grains with normal morphology (mean $=94.1 \%, S D \pm 6.1$ ) was recorded for KA population. In turn, the lowest pollen viability was noted in $\mathrm{PE}$ population (mean $=36.9 \%, S D \pm 6.1$ ). Year-to-year differences were recorded within each population (Fig. $3 \mathrm{c}$ ).
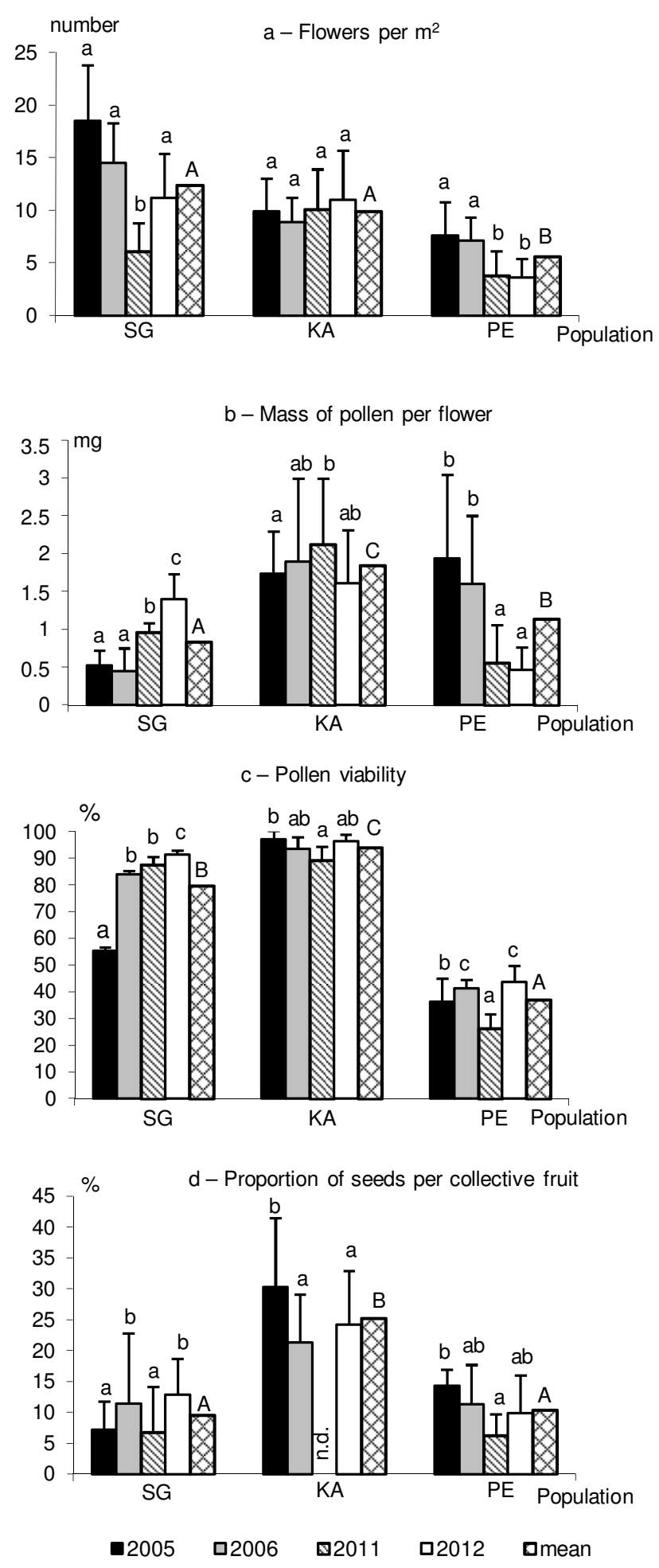

Fig. 3 Differences in the number of flowers per unit area (a), the mass of pollen produced per flower (b), pollen viability (c), and the proportion of seed set per fruit (d) across three populations of Anemone sylvestris in 2005-2006 and 2011-2012. SG, KA, PE - populations. Means with the same small letter do not differ significantly between years within populations and means with the same capital letter do not differ significantly between populations, according to Tukey's test. 


\section{Variability in seed set}

Seed set differed significantly among populations; within each population a year effect was also found (Fig. $3 \mathrm{~d}$ ). The highest reproductive success of Anemone sylvestris was linked to plots located in KA population; the proportion of seed set (mean $=26 \%, S D \pm 9.3$ ) noted in KA was approx. 2.5-fold higher than in SG and PE populations (mean $=9.5 \%, S D$ \pm 6.1 and mean $=10.5 \%, S D \pm 3.7$, respectively).

\section{Discussion}

Population density, seed production or seedling recruitment are considered to determine the long-term chance of species survival in the changing environment [59]. Anemone sylvestris, the rare species of xerothermic grassland, exhibited decrease in the number of individuals, in the abundance of flowering, considerable changes in pollen properties and in the seed production in the case of two out of the three populations studied. The reduction in individuals of A. sylvestris was exacerbated by the expansion of the shrub community, dominated by Prunus spinosa, Cornus sanguinea, or Rhamnus cathartica L. Similarly, in other studies, dominance of the shrub communities on xerothermic patches was responsible for the decrease in the population size of many species, especially heliophytes $[5-7,60]$. The shrub removing intervention undertaken by local authority to prevent grassland overgrowing contributed to the tendency towards restoration of numerous individual plants of $A$. sylvestris. This suggests that the species is sensitive to the competition from juvenile and mature individuals of shrubs and trees. Also Kwiatkowska-Falińska and Faliński [50] reported that A. sylvestris is not able to survive in the areas being covered by shrubs, i.e. Rubus caesius L., Crataegus monogyna Jacq., and trees, i.e. Sorbus aucuparia L. Emend. Hedl. We expect re-colonization of $A$. sylvestris within 3-5 years, the period necessary for heliophytes recovery after shrub-clearing [60].

On the contrary, the expansion by Brachypodium pinnatum did not cause reduction in A. sylvestris population density and individuals blooming, both in short- and longerterm, although the share of $B$. pinnatum, increased in the patch and reached $30 \%$ in the coverage. Brachypodium pinnatum, a large-clonal grass, a CS strategist is regarded as highly competitive species responsible for reduction of floral diversity on thermophilous grasslands [4]. The change in the dynamics of the population with gradual reduction of flowering caused by overgrowing of xerothermic grasslands by $B$. pinnatum was described by Czarnecka [12] in the case of a steppe plant Senecio macrophyllus M. Bieb., also a rhizomatous species. However, some xeric species (e.g. Salvia pratensis, Filipendula vulgaris Moench, Centaurea scabiosa L.) are even favoured by B. pinnatum canopy thinning if the total cover is $15-35 \%$ [61]. It seems $A$. sylvestris belongs to a group. Undoubtedly, the spread of $B$. pinnatum will continue, since the $20-35 \%$ coverage is representative for the middle-successional phase of sward [62], and the graminoid is known to increase in dominance during the transition from grassland to shrub communities [8]. It has been observed that if the coverage of $B$. pinnatum amounted approx. $45-60 \%$ it prevent the development of many steppe plants [62] and promote penetration and colonization of numerous shade-tolerant forest plant species. Therefore, grasslands in the middle-successional stage needs consistent monitoring to prevent expanstion of B. pinnatum over the coverage value that may be dangerous for variety of threaten species of xerothermic grasslands, not only A. sylvestris. The positive short-term response of different perennials to the removal of $B$. pinnatum from patches of calcareous grasslands was documented by Hegedüšová and Senko [11] and Jacquemyn et al. [63].

Additionally, it is likely that internal biological factors contribute to population trajectories in A. sylvestris; and biological factors may act synergistically with vegetation pressures on the degree of seed set. Our results corroborate the opinion of other authors (e.g. reviewed by Manning [36]) that external factors influence the development of androecium and functionality of pollen. Male characteristics of $A$. sylvestris, i.e. pollen amount per multi-stamiante flowers or pollen viability appeared to decrease under pressure of shrub vegetation. One of the possible explanations is reduced light experienced under canopy shade. Light conditions derivative to the exposure to the sun were reported to impact on the number of stamens developed in multi-staminate flowers of heliophilous Adonis vernalis [43]. According to Prasad and Djanaguiraman [64] changes in photosynthesis intensity derivative to light energy changes are responsible for decrease in pollen function, leading in consequence to lower seed-set.

In our study the highest reproductive success was linked with the population which was characterized by the highest amounts of pollen produced and the highest pollen viability. An adequate amount of good quality pollen to complete fertilization of available ovules is one of a variety of factors necessary for seed and fruit set $[27,28,38]$, therefore any disorders in the male function is beginning to have repercussions on the individual reproductive success. The possible consequences of male function problems is a weakening of progeny vigor which in long-term perspective may even negatively apply to the population dynamics as has been confirmed for Ipomopsis aggregate (Pursh) V.E. Grant [65] or Fragaria virginiana Mill. [66]. Similarly, Vange [41] stressed that pollen limitation (quantitative and/or qualitative) activate cascade of reactions; problems in sexual reproduction limit seed set; shortage of seeds aggravate seedling recruitment and establishment. Lack of seed rain or transient seed bank are considered as critical for colonization or re-colonization of open areas by many grassland species $[60,67]$. Therefore specific effort must be given to provide habitat sufficient for generative reproduction of individuals within grasslands.

Besides the changes in light conditions experienced under shrubs canopy, there are other habitat conditions that have been found to change during shrubs invasion, i.e. increased water stress, decreased $\mathrm{C}$ and $\mathrm{N}$ budgets or gradual deterioration of nutrients level in soils [68]. These habitat changes leads to resource heterogeneity [69] and have a considerable impact on the nutritional status of a plant, therefore may impact on seed set both directly by lowering resource pool for seed maturation and indirectly through problems derivative to male function. 
However, our data isn't unequivocally supportive of the impact of male function disorders on weaker seed set; the pollination requirement of the species was not evaluated in the current study. Most models show that pollen limitation in sexual reproduction is more derivative to lack of pollen vectors than to the amount of pollen yield [42,70], therefore further experiment is necessary to define the conditions for sufficient generative reproduction in A. sylvestris, especially to assess the species breeding system and effective pollinators. We observed different insect visitors attracted by A. sylvestris flowers and the characteristic foraging behavior of bees (Apidae), wasps (Vespidae), and flies (Diptera), i.e. sticking their heads down into the flower, where they probably searched for floral reward. It is very likely that factors important for sufficient plant-pollinator interaction to achieve effective pollination differed among populations. Presumably, there are the differences in insect behavior enforced by co-flowering components of phytocoenoses or pollinators guild; both factors are known to impact on inter-population disparities in reproductive success of the plant species [71].

\section{Acknowledgments}

The material from protected species was collected in compliance with Polish law under permit from the Regional Nature Conservator in Lublin. We would like to thank Monika Frant, Anna Sycha for helping in field observations. We are grateful to three anonymous reviewers for valuable comments on an earlier version of the manuscript. Research was supported financially by the Ministry of Science and Higher Education of Poland as a part of statutory activities of the Department of Botany, University of Life Sciences in Lublin (projects OKB/BW/7, OKB/DS/2) and the Department of Geobotany, Institute of Biology and Biochemistry, Maria Curie-Skłodowska University.

\section{Authors' contributions}

The following declarations about authors' contributions to the research have been made: concept of the study: BD, MW; field work: MW, BD; graphs MW; laboratory analysis: $\mathrm{BD}$; statistical analysis: $\mathrm{MW}, \mathrm{BD}$; writing the manuscript: BD, MW.

\section{Competing interests}

No competing interests have been declared.

\section{References}

1. Krauss J, Klein AM, Dewenter IS, Tscharntke T. Effects of habitat area, isolation, and landscape diversity on plant species richness of calcareous grasslands. Biodivers Conserv. 2004;13:1427-1439. http:// dx.doi.org/10.1023/B:BIOC.0000021323.18165.58

2. Willis KJ, van Andel TH. Trees or no trees? The environments of central and eastern Europe during the Last Glaciation. Quat Sci Rev. 2004;23:2369-2387. http://dx.doi.org/10.1016/j.quascirev.2004.06.002

3. Paul W. Migration routes of xerothermic plants into Poland-review of knowledge and hypothesis and research perspectives. In: Ratyńska $\mathrm{H}$, Waldon B, editors. Thermophilous turfs of Poland. Bydgoszcz. Kazimierz Wielki University Press; 2010. p. 55-65.

4. Gömöry D, Dovčiak M, Gömöryová E, Hrivnák R, Janišová M, Ujházy K. Demecological, synecological and genetic aspects of the colonization of abandoned pastures and meadows by forest trees. Zvolen: Technical University in Zvolen, Slovakia; 2006.

5. Wallis de Vries MF, Poschlod P, Willems JH. Challenges for the conservation of calcareous grasslands in northwestern Europe: integrating the requirements of flora and fauna. Biol Conserv. 2002;104:265-273. http://dx.doi.org/10.1016/S0006-3207(01)00191-4

6. Chýlová T, Münzbergová Z. Past land use co-determines the present distribution of dry grassland plant species. Preslia. 2008;80:183-198.
Year-to-year variations in the qualitative and quantitative traits of androecium within populations may be also derivative to climatic conditions. Temperature drops or low precipitation level during microsporogenesis may negatively influence pollen traits, i.e. pollen output $[20,25,54]$ and pollen viability $[26,35]$. Bearing in mind that the frequency of climate anomalies increase and they will progress [72] A. sylvestris may experience different difficulties in the future. For example, temperature, water balance and solar radiation were found to have limiting effect on reproduction and regeneration of rare Pulsatilla vulgaris in lowland Poland [59].

To conclude, it is crucial that successful recovery programs for A. sylvestris primary should aim to conserve and manage the habitat. Unfavorable habitat gradients with the changing environment lead to a decrease in individuals' density and may weaken pollen properties of the species.

In our next study the breeding system and effective pollinators will be reported.

7. Rysiak A. The share of xerothermic species in vascular flora of the city of Lublin (Poland). Acta Agrobot. 2012;65(2):133-146. http:// dx.doi.org/10.5586/aa.2012.067

8. Schlaepfer F. Influence of management on cover and seed production of Brachypodium pinnatum (L.) Beauv. in a calcareous grassland. Bulletin of the Geobotanical Institute ETH. 1997;63:3-10.

9. Cremene C, Groza G, Rakosy L, Schileyko A, Baur A, Erhardt A, et al. Alterations of steppe-like grasslands in Eastern Europe: a threat to regional biodiversity hotspots. Conserv Biol. 2005;19:1606-1618. http://dx.doi.org/10.1111/j.1523-1739.2005.00084.x

10. Bornkamm R. Fifty years vegetation development of a xerothermic calcareous grassland in Central Europe after heavy disturbance. Flora. 2007;201:249-267. http://dx.doi.org/10.1016/j.flora.2005.06.012

11. Hegedüšová K, Senko D. Successional changes of dry grasslands in southwestern Slovakia after 46 years of abandonment. Plant Biosyst. 2011;145(3):666-687. http://dx.doi.org/10.1080/11263504.2011.6 01605

12. Czarnecka B. The dynamics of the population of a steppe perennial Senecio macrophyllus M. Bieb. during xerothermic grassland overgrowing. Acta Soc Bot Pol. 2009;78(3):247-256. http://dx.doi. org/10.5586/asbp.2009.032

13. Dzwonko Z, Loster S. Dynamics of species richness and composition in a limestone grassland restored after tree cutting. J Veg Sci. 1998;9:387-394. http://dx.doi.org/10.2307/3237103

14. Dzwonko Z, Loster S. A functional analysis of vegetation dynamics in abandoned and restored limestone grasslands. J Veg Sci. 2007;18:203212. http://dx.doi.org/10.1111/j.1654-1103.2007.tb02531.x

15. Shirres DA, Bell AD. Rhizome growth and clone development in Anemone nemorosa L. Ann Bot. 1984;54:315-324.

16. Barrett JP, Silander JA. Seedling recruitment limitation in white clover (Trifolium repens, Leguminosae). Am J Bot. 1992;79:643-649. http:// dx.doi.org/:10.2307/2444880

17. Eriksson O. Dynamics of genets in clonal plants. Trends Ecol Evol. 1993;8:313-316. http://dx.doi.org/10.1016/0169-5347(93)90237-J

18. Brunet J, van Oheimb G. Colonization of secondary woodlands by Anemone nemorosa. Nord J Bot. 1998;18:369-377. http://dx.doi. org/10.1111/j.1756-1051.1998.tb01892.x

19. Stehlik I, Holderegger R. Spatial genetic structure and clonal diversity of Anemone nemorosa in late successional deciduous woodlands of Central Europe. J Ecol. 2000;88:424-435. http://dx.doi. org/10.1046/j.1365-2745.2000.00458.x 
20. Denisow B. Pollen production of selected ruderal plant species in the Lublin area. Lublin: University Life Sci. Press; 2011. p. 15-18.

21. Lindell T. Breeding systems and crossing experiments in Anemone patens and in the Anemome pulsatilla group (Ranunculaceae). Nord J Bot. 1998;18(5):549-561. http://dx.doi.org/10.1111/j.1756-1051.1998. tb01535.x

22. Müller N, Schneller JJ, Holderegger R. Variation in breeding system among populations of the common woodland herb Anemone nemorosa (Ranunculaceae). Plant Syst Evol. 2000;221(1-2):69-76. http://dx.doi. org/10.1007/BF01086381

23. Erbar C, Leins P. Nectar production in the pollen flower of Anemone nemorosa in comparison with other Ranunculaceae and Magnolia (Magnoliaceae). Org Divers Evol. 2013;13:287-300. http://dx.doi. org/10.1007/s13127-013-0131-9

24. Denisow B, Bożek M. Blooming biology and pollen production in Anemone japonica Houtt. $=$ Anemone $\times$ hybrida hort. Acta Agrobot. 2006;59(1):139-146. http://dx.doi.org/10.5586/aa.2006.014

25. Pacini E. From anther and pollen ripening to pollen presentation. Plant Syst Evol. 2000;222:19-43. http://dx.doi.org/10.1007/BF00984094

26. Dafni A, Firmago D. Pollen viability and longevity: practical, ecological and evolutionary implications. Plant Syst Evol. 2000;222:113-132. http://dx.doi.org/10.1007/BF00984098

27. Kunin WE. Population size and density effects in pollination: pollinator foraging and plant reproductive success in experimental arrays of Brassica kaber. J Ecol. 1997;85:225-234. http://dx.doi.org/10.2307/2960653

28. Knight T. Floral density, pollen limitation, and reproductive success in Trillium grandiflorum. Oecologia. 2003;442:557-563. http://dx.doi. org/10.1007/s00442-003-1371-8

29. Parachnowitsch AL, Elle E. Variation in sex allocation and male-female trade-offs in six populations of Collinsia parviflora (Scrophulariaceae s.l.). Am J Bot. 2004;91(8):1200-1207. http://dx.doi.org/10.3732/ ajb.91.8.1200

30. Morgan MT, Wilson WG, Knight TM. Plant population dynamics, pollinator foraging, and the selection of self-fertilization. Am Nat. 2005;166:169-183. http://dx.doi.org/10.1086/431317

31. Aizen MA, Harder LD. Expanding the limits of the pollen limitation concept: effects of pollen quantity and quality. Ecology. 2007;99:271281. http://dx.doi.org/10.1890/06-1017

32. Franzén M, Larsson $M$. Seed set differs in relation to pollen and nectar foraging flower visitors in an insect-pollinated herb. Nord J Bot. 2009;27(4):274-283. http://dx.doi. org/10.1111/j.1756-1051.2009.00348.x

33. Gómez JM, Abdelaziz M, Lorite J, Muñoz-Pajares AJ, Perfectti F. Changes in pollinator fauna cause spatial variation in pollen limitation. J Ecol. 2010;98:1243-1252. http://dx.doi. org/10.1111/j.1365-2745.2010.01691.x

34. Ibanez S. Optimizing size thresholds in a plant-pollinator interaction web: towards a mechanistic understanding of ecological networks. Oecologia. 2012;170(1):233-42. http://dx.doi.org/10.1007/ s00442-012-2290-3

35. Cruden RW. Pollen grains: why so many? Plant Syst Evol. 2000;222:143-165. http://dx.doi.org/10.1007/BF00984100

36. Manning JC. Diversity of endothecial patterns in the angiosperms. In: D'Arcy, WG, Keating RC, editors. The anther. Form, function and phylogeny. Cambridge: Cambridge University Press; 1996. p. 136-158.

37. Campbell DR. Experimental tests of sex-allocation theory in plants. Trends Ecol Evol. 2000;15:227-231. http://dx.doi.org/10.1016/ S0169-5347(00)01872-3

38. Larson BMH, Barrett CHB. A comparative analysis of pollen limitation in flowering plants. Biol J Linn Soc Lond. 2000;69:503-520. http:// dx.doi.org/10.1006/bijl.1999.0372

39. Barrett SCH, Eckert CG. Current issues in plant reproductive ecology. Israel Journal of Botany. 1990;39:5-12. http://dx.doi.org/10.1080/00 21213X.1990.10677130

40. Douglas KL, Cruden RW. The reproductive biology of Anemone canadensis (Ranunculaceae): breeding system and facilitation of sexual selection. Am J Bot.1994;81:314-321. http://dx.doi. org/10.2307/2445458

41. Vange V. Breeding system and inbreeding depression in the clonal plant species Knautia arvensis (Dipsacaceae): implications for survival in abandoned grassland. Biol Conserv. 2002;108(1):59-67. http:// dx.doi.org/10.1016/S0006-3207(02)00090-3

42. Ashman TL, Knight TM, Steets J, Amarasekare P, Burd M, Campbell $\mathrm{DR}$, et al. Pollen limitation of plant reproduction: ecological and evolutionary causes and consequences. Ecology. 2004;85:2408-2421. http://dx.doi.org/10.1890/03-8024

43. Denisow B, Wrzesień M. The study of blooming and pollen efficiency of Adonis vernalis $\mathrm{L}$. in xerothermic plant communities. J Apic Sci. 2006;50(1):25-32.

44. Czarnecka B, Denisow B. Floral biology of Senecio macrophyllus M. BIEB. (Asteraceae), a rare Central European steppe plant. Acta Soc Bot Pol. 2014;83(1):17-27. http://dx.doi.org/10.5586/asbp.2014.002

45. Denisow B, Wrzesień M, Cwener A. The estimation of Adonis vernalis L. populations in chosen patches of Lublin Upland. Acta Agrobot. 2008;61(1):3-11. http://dx.doi.org/10.5586/aa.2008.001

46. Denisow B, Wrzesień M, Cwener A. Pollination and floral biology of Adonis vernalis L. (Ranunculaceae) - a case study of threatened species. Acta Soc Bot Pol. 2014;83(1):29-37. http://dx.doi.org/10.5586/ asbp.2014.001

47. Klotz S, Kühn I, Durka W, editors. BiolFlor Eine Datenbank zu biologischökologischen. Merkmalen der Gefäßpflanzen in Deutschland. Schriftenreihe für Vegetationskunde, 38. Bonn: Bundesamt für Naturschutz; 2002

48. Ehrendorfer F, Ziman AN, König C, Keener CS, Dutton BE, Tsarenko ON, et al. Taxonomic revision, phylogenetics and transcontinental distribution of Anemone section Anemone (Ranunculaceae). Bot J Linn Soc. 2009;160:312-354. http://dx.doi. org/10.1111/j.1095-8339.2009.00861.x

49. Zając M, Zając A. Elementy geograficzne rodzimej flory Polski. Kraków: Uniwersytet Jagielloński; 2009.

50. Kwiatkowska-Falińska JA, Faliński JB. Conditions of occurrence of Anemone sylvestris in a kettle hole in north-eastern Poland. Acta Soc Bot Pol. 2007;76(2):133-140. http://dx.doi.org/10.5586/asbp.2007.017

51. van der Maarel E. Transformation of cover-abundance values in phytosociology and its effects on community similarity. Vegetatio. 1979;29:97-114. http://dx.doi.org/10.1007/BF00052021

52. Matuszkiewicz W. Przewodnik do oznaczania zbiorowisk roślinnych Polski. Warszawa. Polish Scientific Publishers PWN; 2006

53. Mirek Z, Piekoś-Mirkowa H, Zając A, Zając M. Flowering plants and pteridophytes of Poland a checklist. In: Mirek Z, editor. Biodiversity of Poland. Cracow: W. Szafer Institute of Botany, Polish Academy of Sciences; 2002. (vol 1).

54. Denisow B. Pollen production, flowering and insect visits on Euphorbia cyparissias L. and Euphorbia virgultosa Klok. J Apic Res. 2009;48(1):50-59. http://dx.doi.org/10.3896/IBRA.1.48.1.11

55. Climate data: Poland-Włodawa, Zamość, Radawiec [Internet]. 2015 [cited 2015 Mar 18]; Available from: http://en.tutiempo.net/climate/

56. Kovach WL. MVSP A Multivariate Statistical package for Windows ver.3.1. Wales: Kovach Computing Services, Pentraeth; 2007.

57. ter Braak CJF, Smilauer P. CANOCO reference manual and Canodraw for Windows. User's guide: Software for ordination (ver. 5.0). Wageningen: Biometric; 2012.

58. Stanisz A. Przystępny kurs statystyki z zastosowaniem Statistica na przykładach z medycyny. Kraków; Statsoft Polska; 2007.

59. Grzyl A, Kiedrzyński M, Zielińka KM, Rewicz A. The relationship between climatic conditions and generative reproduction of a lowland population of Pulsatilla vernalis: the last breath of a relict plant or a fluctuating cycle of regeneration? Plant Ecol. 2014;215:457-466. http:// dx.doi.org/10.1007/s11258-014-0316-0

60. Barbaro L, Dutoit T, Cozic P. A six-year experimental restoration of biodiversity by shrub-clearing and grazing in calcareous grasslands 
of the French Prealps. Biodivers Conserv. 2001;10:119-135. http:// dx.doi.org/10.1023/A:1016629507196

61. Trąba C, Wolański P, Oklejewicz K. Communities with Brachypodium pinnatum and Bromus erectus in the Wiar and the San Valley. Ann UMCS Biol. 2012;67(1):69-92. http://dx.doi.org/10.2478/ V10067-012-0014-Z

62. Virágh K, Bartha S. Species turnover as a function of vegetation pattern. Tiscia. 2003;34:47-56.

63. Jacquemyn $\mathrm{H}$, Butaye J, Hermy M. Impacts of restored patch density and distance from natural forests on colonization success. Restor Ecol. 2003;11(4):417-423. http://dx.doi.org/10.1046/j.1526-100X.2003. rec0237.x

64. Prasad V, Djanaguiraman M. High night temperature decreases leaf photosynthesis and pollen function in grain sorghum. Funct Plant Biol. 2011;38(12):993-1003. http://dx.doi.org/10.1071/FP11035

65. Campbell DR, Halama KJ. Resource and pollen limitations to lifetime seed production in a natural plant population. Ecology. 1993;74:10431051. http://dx.doi.org/10.2307/1940474

66. Kalla SE, Ashman TL. The effects of pollen competition on progeny vigor in Fragaria virginiana (Rosaceae) depend on progeny growth environment. Int J Plant Sci. 2002;163(2):335-340. http://dx.doi. org/10.1086/338395
67. Bullock JM, Clear Hill B, Dale MP, Silvertown J. An experimental study of the effects of sheep grazing on vegetation change in a species-poor grassland and the role of seedling recruitment into gaps. J Appl Ecol. 1994;31:493-507. http://dx.doi.org/10.2307/2404445

68. Corcket E, Liancourt P, Callaway RM, Michalet R. The relative importance of competition for two dominant grass species, as affected by environmental manipulations in the field. Ecoscience. 2003;10(2):186-194.

69. Reader RJ, Bonser SP. Control of plant frequency on an environmental gradient: effects of abiotic variables, neighbours, and predators on Poa pratensis and Poa compressa (Gramineae). Can J Bot. 1993;71(4):592-597. http://dx.doi.org/10.1139/b93-067

70. Muchhala N, Thomson JD. Fur versus feathers: pollen delivery by bats and hummingbirds and consequences for pollen production. Am Nat. 2010;175:717-726. http://dx.doi.org/10.1086/652473

71. Goulson D. Foraging strategies of insects for gathering nectar and pollen, and implications for plant ecology and evolution. Perspect Plant Ecol Evol Syst. 1999;2:185-209. http://dx.doi. org/10.1078/1433-8319-00070

72. Kundzewicz ZW, Radziejewski M, Pińskwar J. Principation extremes in the changing climate of Europe. Clim Res. 2006;31:51-58. http:// dx.doi.org/10.3354/cr031051 